\title{
Biological Management of Damping off Disease of Tomato Cause by Pythium aphanidermatum
}

\author{
B. Bora ${ }^{\text {* }}$ and B. C. Deka ${ }^{2}$ \\ ${ }^{1}$ Department of Plant Pathology, Biswanath College of Agriculture, \\ Biswanath Chariali, Assam, India \\ ${ }^{2}$ Krishi Vigyan Kendra, Lakhimpur, Assam, India \\ *Corresponding author
}

A B S T R A C T

\begin{tabular}{l} 
K e y w o r d s \\
Damping off, \\
Bioveer, Biofor PF- \\
2, Biomonas and \\
Biozin PTB \\
\hline Article Info \\
$\begin{array}{l}\text { Accepted: } \\
18 \text { April } 2020 \\
\text { Available Online: } \\
10 \text { May } 2020\end{array}$
\end{tabular}

Keywords

Damping off,

Bioveer, Biofor PF

Biozin PTB

Article Info

Accepted:

Available Online

10 May 2020
Talc based bioformulations namely Biofor PF-2, Bioveer, Biomonas and Biozin PTB were evaluated against damping off disease of tomato. Application of these bioformulations as seed treatment and in nursery bed treatment before sowing significantly reduced the pre- and post-emergence damping off of tomato. Among all the bioformulations tested, Biozin PTB was found most effective in reducing maximum (76.68 and 70.76 per cent) reduction of pre- and post-emergence damping off of tomato. Besides reducing the pre- and post-emergence damping off, Biozin PTB also caused maximum increase of root length, shoot length and biomass production of tomato seedlings.

\section{Introduction}

Tomato (Lycopersicon esculentum Mill) is one of the most popular vegetable crops, grown all over the country and it is also widely cultivated in Assam. The crop is attacked by several diseases, caused by fungi, bacteria and viruses leading to severe crop losses. Among the fungal diseases, the damping off disease incited by Pythium aphanidermatum is a major constraint in the production of tomato. Pythium spp. are essentially soil borne (Berkley, 1925; Horsfall, 1930) and pose a serious problem in the management of this disease.

Fungicides are mostly used to manage the disease in nurseries but frequent and indiscriminate use of fungicides often leads to atmospheric pollution and development of fungicide resistance in pathogens which necessitates an alternative eco-friendly 
method for its management and sustainable crop production. In this context, biological control appears to be an alternative strategy for its management which is environment friendly, safe and cost effective. Several microorganisms have been successfully used as biocontrol agents, such as Trichoderma spp. (Raguchander et al., 1997), Bacillus spp. (Copper and Campbell, 1986), Trichoderma spp and Bacillus spp (Jeyaseelan, et al., 2012) and Pseudomonas spp. (Vidhyaksekaran and Muthamilan, 1995). Therefore, in the present study an attempt was made to assess the efficacy of these talc-based bioformulations against damping off disease of tomato caused by the pathogen Pythium aphanidermatum

\section{Materials and Methods}

Talc based bioformulations namely Biofor PF-2 containing Pseudomonas fluorescens and Trichoderma harzianum, Bioveer containing Trichoderma viride, Biomonas containing Pseudomonas fluorescens and Biozin PTB containing Pseudomonas aeruginosa, Trichoderma harzianum and Bacillus brevis obtained from the department of Plant Pathology, Assam Agricultural University, Jorhat were used in the present study. These were used to treat the seeds @ $10 \%$ (100gm in 1 litre water) and dry under shade for $1 \mathrm{hrs}$ before sowing. The same formulations were also applied to nursery beds@2\% before sowing by mixing 1kg formulation with 50 litre water and drench the nursery soil before sowing. The seeds of cv. Pusa Ruby were sown in lines @ 50 seed /line and there were 8 lines / bed. There were six treatments with four replications and randomized block design was followed for this experiment. The fungicide copper oxychloride $(0.25 \%)$ served as standard check was used as soil drench @ 2 litres / m2. The beds were irrigated daily using rose can. The incidence of pre-and post emergence damping-off was recorded. Vigour indices were calculated by following the standard procedure given by Abdul-Baki and Anderson (1973).

\section{Results and Discussion}

The data presented in Table 1 showed that all the treatments significantly reduced pre-and post-emergence damping off of tomato. Application of Biozin PTB recorded minimum (6.12 and 8.28 per cent) pre- and post-emergence damping-off followed by Biofor PF and Biomonas, respectively. The highest (26.24 and 28.32 per cent) incidence of pre- and post-emergence damping-off was observed in control. Biozin PTB caused 76.68 and 70.76 per cent reduction in pre- and postemergence damping off, respectively, over control which is followed by Biofor PF (66.54 and 63.35) and Biomonas (60.67 and 56.81), respectively in reduction in pre- and postemergence damping off over control. Soil application of antagonists significantly reduced the preand post-emergence damping off of tomato as reported by Ramanathan (1989) who observed that soil application with of $T$. viride was more effective than seed pelleting for the control of pre- and postemergence damping off in chilli caused by $P$. aphanidermatum. Similar observation was also observed by Manorantitham, et al., (2001) who reported that application of talc based formulation of Trichoderma viride and Pseudomonas fluorescens in nursery beds before sowing significantly reduced the damping-off of tomato caused by Pythium aphanidermatum

The data regarding the effect of bioformulations on the growth of tomato seedlings presented in Table 2 indicated that application of Biozin PTB recorded the maximum per cent increase in shoot length (32.31), root length (45.21) and dry matter production (51.65) over control which was followed by Biofor PF and Biomonas, 
respectively. The effect of Bioveer in enhancing the growth of tomato seedlings was at par with the fungicide copper oxychloride. In the present study, application of talc-based bioformulation (Biozin PTB) increased the root and shoot length and dry matter production in tomato over all the treatments. This is in agreement with the findings of Ramanathan (1989) and Mayavaramban (1994) who worked on damping off disease of chilli. Soil application of $T$. harzianum increased seedling vigour in cucumber and pepper as observed by Inbar et at. (1994). The present result is in conformity with the findings of Manorantitham, et al., (2001) who observed that soil application of talc based formulation of Trichoderma viride and Pseudomonas fluorescens significantly increased the root length, shoot length and biomass production of tomato seedlings.

Table.1 Effect of bioformulations on damping off of tomato under field condition

\begin{tabular}{|l|c|c|c|c|}
\hline \multirow{2}{*}{ Treatments } & \multicolumn{4}{|c|}{ Percent incidence of damping off disease } \\
\cline { 2 - 5 } & Pre emergence & $\begin{array}{c}\text { Percent } \\
\text { reduction } \\
\text { over control }\end{array}$ & Post emergence & $\begin{array}{c}\text { Percent reduction } \\
\text { over control }\end{array}$ \\
\hline Biofor PF & $8.78(17.23)^{\mathrm{e}}$ & 66.54 & $10.38(18.79)^{\mathrm{e}}$ & 63.35 \\
\hline Biomonas & $10.32(18.75)^{\mathrm{d}}$ & 60.67 & $12.24(20.47)^{\mathrm{d}}$ & 56.81 \\
\hline Bioveer & $12.24(20.48)^{\mathrm{b}}$ & 53.35 & $13.78(21.79)^{\mathrm{b}}$ & 51.34 \\
\hline Biozin PTB & $6.12(14.34)^{\mathrm{f}}$ & 76.68 & $8.28(16.73)^{\mathrm{f}}$ & 70.76 \\
\hline $\begin{array}{l}\text { Copper } \mathbf{0 x y c h l o r i d e} \\
\mathbf{( 0 . 2 5 \% )}\end{array}$ & $11.36(19.71)^{\mathrm{c}}$ & 56.71 & $12.76(20.93)^{\mathrm{c}}$ & 54.94 \\
\hline Control & & & & \\
\hline CD (P = 0.05) & $26.24(30.81)^{\mathrm{a}}$ & & $28.32(32.16)^{\mathrm{a}}$ & \\
\hline
\end{tabular}

Mean of 4 replications

Figures in parentheses are arcsine transformed values

Table. 2 Effect of bioformulations on the growth of tomato seedlings under field conditions

\begin{tabular}{|l|l|c|c|c|c|c|}
\hline \multicolumn{1}{|c|}{ Treatments } & $\begin{array}{l}\text { Shoot } \\
\text { length }\end{array}$ & $\begin{array}{c}\text { Percent } \\
\text { increase } \\
\text { over } \\
\text { control }\end{array}$ & $\begin{array}{c}\text { Root } \\
\text { length }\end{array}$ & $\begin{array}{c}\text { Percent } \\
\text { increase } \\
\text { over } \\
\text { control }\end{array}$ & $\begin{array}{c}\text { Dry matter } \\
\text { production }\end{array}$ & $\begin{array}{c}\text { Percent } \\
\text { increase } \\
\text { over } \\
\text { control }\end{array}$ \\
\hline Biofor PF & $13.34 \mathrm{~b}$ & 27.53 & $2.39 \mathrm{~b}$ & 37.16 & $0.964 \mathrm{~b}$ & 48.77 \\
\hline Biomonas & $12.87 \mathrm{c}$ & 23.01 & $2.28 \mathrm{c}$ & 31.03 & $0.943 \mathrm{c}$ & 45.47 \\
\hline Bioveer & $12.26 \mathrm{~d}$ & 17.21 & $2.14 \mathrm{~d}$ & 23.18 & $0.926 \mathrm{~d}$ & 43.31 \\
\hline Biozin PTB & $13.84 \mathrm{a}$ & 32.31 & $2.53 \mathrm{a}$ & 45.21 & $0.983 \mathrm{a}$ & 51.65 \\
\hline $\begin{array}{l}\text { Copper oxychloride } \\
\text { (0.25\%) }\end{array}$ & $12.37 \mathrm{~d}$ & 18.23 & $2.18 \mathrm{~d}$ & 25.48 & $0.929 \mathrm{~d}$ & 43.31 \\
\hline Control & $10.46 \mathrm{e}$ & & $1.74 \mathrm{e}$ & & $0.648 \mathrm{e}$ & \\
\hline CD (P= 0.05) & 0.322 & & 0.091 & & 0.011 & \\
\hline
\end{tabular}

Mean of 4 replications 
They recorded that the reduction in population of $P$. aphanidermatum in the soil due to application of antagonists formulation might be the reason for lesser incidence of pre and post-emergence damping off of tomato. The antagonists in soil compete with the pathogen and bring down the inoculums level of the pathogen there by reducing the incidence of pre and post emergence damping off.

Moreover, the enhanced seedling vigour due to the application bioformulation (Biozin PTB) might have contributed towards reduction damping off in tomato. From the present study it may be concluded that application bioformulation (Biozin PTB) as seed treatment as well as nursery treatment not only increased the growth of tomato seedlings but also contributed in the reduction of damping off disease of tomato.

\section{References}

Abdul-Baki, A.A. and Anderson, J.D. (1973). Vigour determination in soybean seed by multiple criteria. Crop Sci. 18: 630633.

Berkley, G.H. (1925). Tomato diseases. Bull. Canada Dept. Agric. Div. Bot. Expt. Farmers Branch, 51 pp.

Copper, A.L. and Campbell, R. (1986). The effect of artificially inoculated antagonistic bacteria on the prevalence of take-all disease of wheat in field experiments. J. Appl. Bacteriol. 60: 155-160.

Horsfall, J.G. (1930). Combating damping off of tomato by seed treatment. Bull New
York State Agric. Expt. Sta.586: 1-22. Jeyaseelan, E.C., Tharmila, S. and Niranjan, K. (2012). Antagonistic activity of Trichoderma spp. and Bacillus spp. against Pythium aphanidermatum isolated from tomato damping off. Arch. Appl. Sci. Res., 4 (4):1623-1627.

lnbar, J., Abramsky, M., Cohan, D. and Chet, I. (1994). Plant growth enhancement and disease control by Trichoderma harzianum in vegetable seedling grown under commercial condition. Euro. J. Pl. Path. 100: 236-436.

Manorantitham, S.K., Prakasam, V. and Rajappan, K. (2001). Biocontrol of damping off of tomato caused by Pythium aphanidermatum. Indian Phytopath. 54 (1) : 59-61.

Mayavaramban, F.S. (1994). Management of damping off of chilli (Capsicum annuum L.) caused by Pythium aphanidermatum (Edson) Fitz. with biocontro1 agents. M.sc (Ag) Thesis, TNAU, Coimbatore, India $89 \mathrm{p}$.

Raguchander, T., Rajappan, K. and Samiyappan, R. (1997). Evaluating methods of application of biocontrol agent in the control of mungbean root rot. Indian Phytopath. 50: 229-234.

Ramanathan, A. (1989). Biocontrol of damping off disease of chilli due to Pythium aphanidermatum (Edson) Fitz. M.Sc. (Ag) Thesis, TNAU, Coimbatore, India, $99 \mathrm{p}$.

Vidhyasekaran, P. and Muthamilan, M. (1995). Development of formulations of Pseudomonas fluorescens for control of chickpea wilt. Plant Dis. 79: 782-786.

\section{How to cite this article:}

Bora, B. and Deka, B. C. 2020. Biological Management of Damping off Disease of Tomato Cause by Pythium aphanidermatum. Int.J.Curr.Microbiol.App.Sci. 9(05): 2407-2410. doi: https://doi.org/10.20546/ijcmas.2020.905.274 